\title{
FEATURES OF LEGISLATIVE PROVISION OF LAND RELATIONS IN PLANNING SPATIAL DEVELOPMENT OF TERRITORIAL COMMUNITIES
}

B. Avramchuk PhD in economic sciences, Land Management Institute of the National Academy of Agrarian Sciences of Ukraine, e-mail: avramchuk.bogdan@gmail.com

O. Kravchenko, National University of Life and Environmental Sciences of Ukraine I.-O. Zastulka, National University of Life and Environmental Sciences of Ukraine

D. Tretiachenko, National University of Life and Environmental Sciences of Ukraine

Abstract. Features of normative-legal maintenance of regulation of land relations in the context of changes to the domestic legislation are considered.

The main threats facing land management specialists in planning the spatial development of territorial communities are highlighted. In addition, the features of a comprehensive plan of spatial development of the territorial community as urban planning documentation at the local level and land management documentation at the same time, as well as the concept of integrated development of the territorial community. Also, in the context of planning the spatial development of the territory and establishing restrictions on land use, the legal aspects of the functional zones of the territory proposed by the Law of Ukraine "On Amendments to Certain Legislative Acts of Ukraine on Land Use Planning " are considered.

The changes in the land legislation regarding the powers to dispose of state and communal lands, as well as the peculiarities of the use of privately owned lands have been studied. Changes to the content of the intended purpose as information of the State Land Cadastre are analyzed, taking into account changes to the regulatory support of the concept of the type of land use.

The key principles of improvement and adoption of bylaws in order to harmonize the current state of regulation of land relations and future planning of spatial development of territorial communities are proposed.

Keywords: legislative provision, land relations, normative legal acts, spatial planning, territorial communities.

Formulation of the problem. Currently, in the context of decentralization of power, land reform is undergoing changes due to the transfer of a number of powers to dispose of land in the hands of territorial communities. Given the fact that in accordance with the Law of Ukraine № 552-XI “On Amendments to 
Certain Legislative Acts of Ukraine on the Conditions of Circulation of Agricultural Land", adopted on March 31, 2020, agricultural land may be in free market circulation, including land plots for commodity agricultural production and for personal farming (shares), the issues of rational use and protection of lands, preservation of soil fertility and sound spatial planning of the territory is extremely acute.

Therefore, the analysis of changes to the legislative support for the regulation of land relations in the spatial planning of territorial communities, including united (OTG), in the context of decentralization of power.

Analysis of recent research and publications. The problem of land use formation in the process of spatial development in Ukraine is an urgent issue. Significant contribution to the development of theoretical and methodological foundations of spatial development of territorial communities was made by such scientists as P. Borshchevskyi, A. Tretiak, Y. Dorosh, A. Martyn, D. Dobriak, M. Khvesyk. At the same time, the issue is extremely relevant and needs further research. Also of considerable scientific interest are the works of such scientists as V. Andreitsev, H. Baliuk, A. Bobkova, A. Hetman, N. Halchynska, S. Yelkin, T. Kovalchuk, T. Kovalenko, M. Kovalchuk and other scientists.

The purpose of the article to analyze the features of the legislative support for the regulation of land relations in the process of development and implementation of comprehensive plans for spatial development of the territorial community.

Presentation of the main material. Disclosing the issues of spatial planning of territorial communities, including OTG, it should be noted, first of all, that in 2018 the order of the Cabinet of Ministers of Ukraine № 60-r from 31.01.2018 "The issue of transfer of state-owned agricultural land to communal ownership united territorial communities" [1] The State Geocadastre was instructed to form land plots agricultural land of state ownership within the defined long-term plan for the formation of community territories, by conducting an 
inventory of agricultural lands of state ownership with the subsequent transfer of these lands to communal ownership. united territorial communities [1].

In addition, the same order stipulated that prior to the transfer of state lands to communal ownership, the transfer of state-owned agricultural land to ownership or use (by auction) must be carried out with the consent of the united territorial communities.

Thus, the adoption of the above order by the Cabinet of Ministers of Ukraine was intended to encourage territorial communities to unite, as, as noted earlier, approval of the transfer of state lands to ownership or use was not within the powers of non-united territorial communities.

Another legal document aimed at regulating the disposal of agricultural land was the Law of Ukraine № 2498-VIII of 10.07.2018 “On Amendments to Certain Legislative Acts of Ukraine on Resolving the Issue of Collective Land Ownership, Improving Land Use Rules in Land Areas" agricultural purposes, prevention of raiding and stimulation of irrigation in Ukraine". The main novelty of this Law was the amendments to the Land Code of Ukraine, namely paragraph 21 of the Transitional Provisions, according to which the lands of collective agricultural enterprises that have been terminated (except for land plots that were privately owned on the day of entry into force) are considered communities in which they are located. This Law is the basis for state registration of communal property rights to land formed at the expense of land, which by virtue of this Law is transferred to communal property" [2].

Thus, the amendments to the legislation marked the beginning of the transfer of powers to dispose of lands outside settlements (state-owned lands and lands of discontinued collective agricultural enterprises) into the hands of territorial communities and, at the same time, encourage the formation of united territorial communities.

Along with stimulating the unification of territorial communities, the order of the Cabinet of Ministers "On the transfer of agricultural land of state ownership to the communal property of the united territorial communities" initiated a state 
inventory of land. However, at the time of the adoption of this normative legal act, the land inventory procedure in force at that time did not provide for the implementation of land inventory works without a statement or request of the owners (users).

Therefore, on June 5, 2019, the Cabinet of Ministers of Ukraine adopted Resolution № 476 “On Approval of the Procedure for Conducting Land Inventory and Recognition of Certain Resolutions of the Cabinet of Ministers of Ukraine as Repealed" [3]. According to this document, the concept of "state land inventory" was enshrined, which "is provided by the State Geocadastre or its territorial body by adopting an order to conduct a state land inventory" [3]. Such an inventory "is carried out by forming land plots regardless of the form of ownership, determining their lands and, if necessary, assigning such land plots to certain categories for information content of the State Land Cadastre" [3].

As a result of large-scale work on the state land inventory, today the State Land Cadastre is filled with a significant number of formed land plots, including agricultural land.

One of the important stages in the formation of legislative support for land regulation in the context of decentralization of power was adopted on 31.03.2020 Law of Ukraine № 552-IX "On Amendments to Certain Legislative Acts of Ukraine on the conditions of circulation of agricultural land". According to this document, starting from July 1, 2021, Article 130 of the Land Code of Ukraine stipulates that territorial communities, along with the state, citizens of Ukraine and legal entities established and registered under domestic law, may acquire ownership of agricultural land [4 ]. It should be noted that today Article 130 of the Land Code regulates the issue of buyers and the preemptive right to purchase agricultural land and land for commercial agricultural production.

The Law of Ukraine № 711-IX of 17.06.2020 “On Amendments to Certain Legislative Acts of Ukraine on Land Use Planning" introduces new planning documentation, which is both urban and land management. Such documentation from July 24, 2021 includes "comprehensive plans for spatial development of 
territorial communities, general plans of settlements, detailed plans of territories" [5]. In this case, according to this Law, the developer of such documentation must be a business entity that can develop urban planning documentation in accordance with the law and a certified land surveyor who is responsible.

It should be emphasized that in accordance with the approved comprehensive plan of spatial development of the territorial community, the general plan of the settlement and the detailed plan of the territory, according to the mentioned Law, land plots are formed, as in the state land inventory, and the category of lands. Therefore, there is a potential threat of reduction of land management works, as envisaged by the formation of land plots within the lands of communal property of territorial communities. Thus, from July 2021, significant restrictions are created for specialists in the field of land management: on the one hand, the preparation of new documentation requires being a business entity that can develop urban planning documentation in accordance with the law; on the other hand, the possibility of forming land plots according to the specified documentation will potentially lead to a reduction of land management works with the formation of land plots.

Regarding the legal aspects, it is important to note that the approval of documentation, which is both urban and land management, is the responsibility of the relevant village, town and city councils, which in accordance with the Law of Ukraine № 280/97-VR of 21.05.1997 “On local self-government in Ukraine” represent the common interests of territorial communities of villages, settlements, cities [6].

Thus, the above-mentioned Law stipulates that the powers of territorial communities also include the disposal of communal lands outside settlements. That is, communities can make decisions regarding all lands within the territory of territorial communities, except for state-owned lands, which according to the law cannot be transferred to communal ownership. 


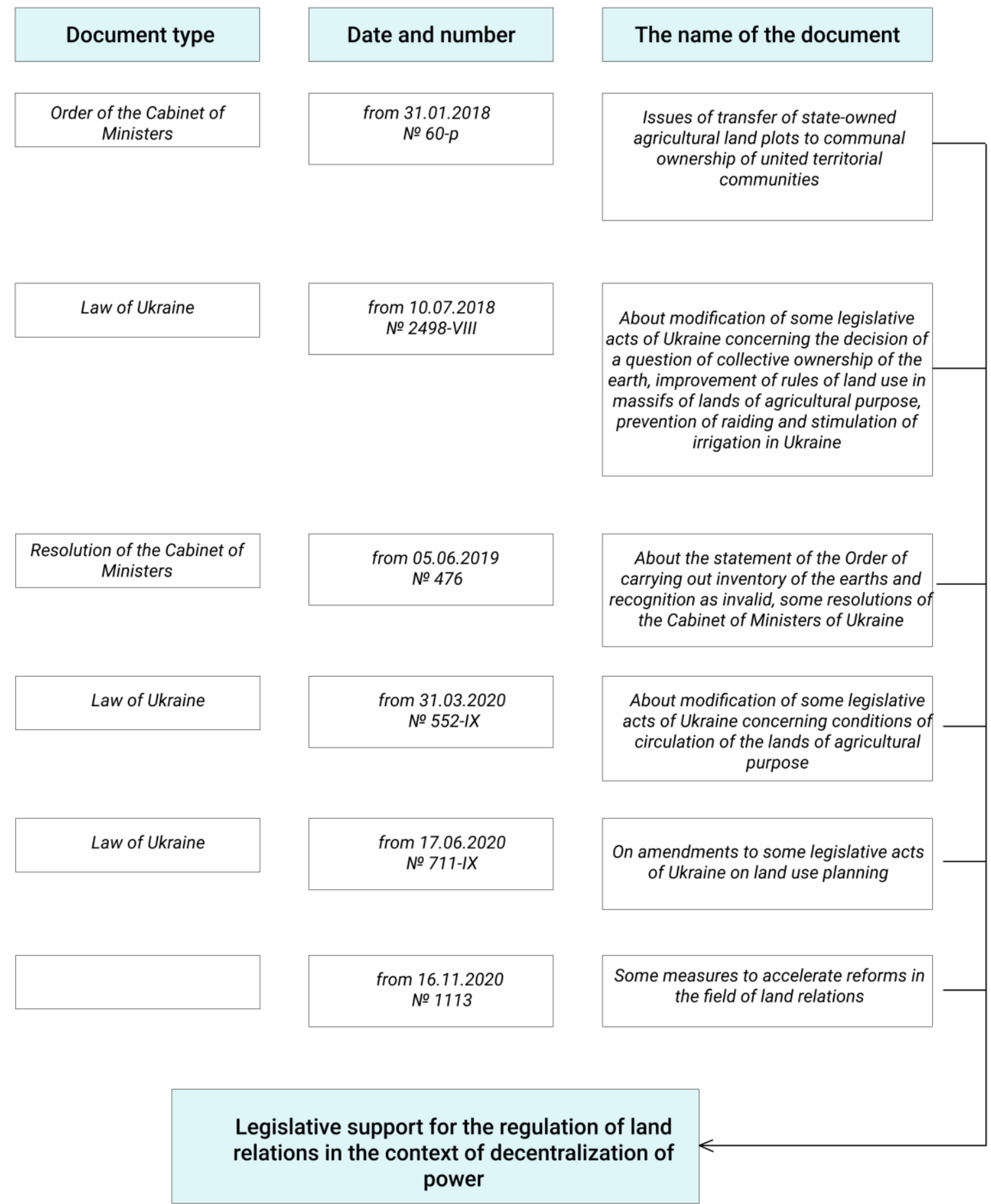

Fig. 1. The scheme of legislative acts on the regulation of land relations for the period 2018 to 2020

An indicator of accelerating the process of decentralization of power and adoption of appropriate legislative support for land reform is the adoption by the Cabinet of Ministers of Ukraine Resolution № 1113 of 16.11.2020. "Some measures to accelerate reforms in land relations", which is essentially a repetition of the CMU Order № 60-r from January 31, 2018 "The issue of transfer of 
agricultural land of state ownership in the communal property of the united territorial communities". At the same time, the Resolution of the Cabinet of Ministers of Ukraine № 1113 recommends that "local self-government bodies register the right of communal ownership of the received agricultural land plots in accordance with the procedure established by law" [7].

Thus, the above document, as well as the previous ones, did not take steps to ensure the status of territorial communities, including united as a body of local self-government without their representation by village, settlement and city councils.

That is why today the key principles of improving the adopted laws and bylaws are to justify the role of territorial communities, including united, when making decisions on land management in order to minimize corruption and speculative risks that may arise in local governments.

Conclusion. It is established that in accordance with Part 3 of Article 2 of the Land Code of Ukraine, the objects of land relations are land plots and rights to them, not "territories", the status of which is defined in the Law of Ukraine "On Amendments to Certain Legislative Acts of Ukraine lands ", which enters into force on 24.07.2021. It is also not the subject of the Civil Code of Ukraine and the regulation of relations in the field of urban planning (in particular, spatial development of communities, master plans of settlements, detailed plans of territories, comprehensive plans of spatial development of communities, etc.). In this regard, we propose to make appropriate changes to the Land Code of Ukraine.

\section{Reference}

1. Order of the Cabinet of Ministers of 31.01.18 № 60-r "Issues of transfer of agricultural land of state ownership to the communal property of the united territorial communities". Available at: https://www.kmu.gov.ua/npas/pitannya-peredachi-1

2. Law of Ukraine of July 10, 2018 № 2489-VIII “On Amendments to Certain Legislative Acts of Ukraine on Resolving the Issue of Collective Land Ownership, Improving the Rules of Land Use in Agricultural Land, Preventing Raids and Stimulating Irrigation in Ukraine". Available at: https://zakon.rada.gov.ua/laws/show/2498-19\#Text 
3. Resolution of the Cabinet of Ministers of 05.06.2019 № 476 "On approval of the Procedure for conducting an inventory of lands and recognizing as invalid some resolutions of the Cabinet of Ministers of Ukraine". Available at: https://zakon.rada.gov.ua/laws/show/476-2019-\%D0\%BF\#Text

4. Law of Ukraine of 31.03.2020 № 552-IX “On Amendments to Certain Legislative Acts of Ukraine Concerning the Conditions of Circulation of Agricultural Lands". Available at: https://zakon.rada.gov.ua/laws/show/2498-19\#Text

5. The Law of Ukraine of June 17, 2020 № 711-IX “On Amendments to Certain Legislative Acts of Ukraine Concerning Land Use Planning”. Available at: https://zakon.rada.gov.ua/laws/show/711-20\#Text

6. The Law of Ukraine of 21.05.1997 № 280/97-VR “On Local Self-Government in Ukraine" "represents the common interests of territorial communities of villages, settlements and cities". Available at: https://zakon.rada.gov.ua/laws/show/280/97$\% \mathrm{D} 0 \% \mathrm{~B} 2 \% \mathrm{D} 1 \% 80$

7. Resolution of the Cabinet of Ministers of 16.11.2020 № 1113 "Some measures to accelerate reforms in the field of land relations". Available at: https://www.kmu.gov.ua/npas/deyaki-zahodi-shchodo-priskorennya-reform-u-sferi$\underline{\text { zemelnih-vidnosin-i161120-1113 }}$

8. Dobrak D. (2004). Teoretychni zasady staloho rozvytku zemlekorystuvannya u sil's'komu hospodarstvi [Theoretical principles of sustainable development of land use in agriculture]. Yrojay, 136 [in Ukraine].

9. Kovalchuk T. (2006). Problema efektyvnoho zemlekorystuvannya v Ukrayini [The problem of effective land use in Ukraine]. Banking, 1, 6-16 [in Ukraine].

Аврамчук Б.О., Кравченко О.М., Застулка І.-О.Ю., Третяченко Д.В. ОСОБЛИВОСТІ ЗАКОНОДАВЧОГО ЗАБЕЗПЕЧЕННЯ ЗЕМЕЛЬНИХ ВІДНОСИН ПРИ ПЛАНУВАННІ ПРОСТОРОВОГО РОЗВИТКУ ТЕРИТОРІАЛЬНИХ ГРОМАД

Анотація. Розглянуто особливості нормативно-правового забезпечення регулювання земельних відносин в контексті змін до вітчизняного законодавства.

Висвітлено основні загрози, що постають перед спеціалістами землевпорядної сфери при плануванні просторового розвитку 
територіальних громад. Крім того, проаналізовано особливості комплексного плану просторового розвитку територї територіальної громади як містобудівної документації на місиевому рівні та документації із землеустрою одночасно, а також концеепиії інтегрованого розвитку територіі територіальної громади. Також, в контексті планування просторового розвитку території та встановлення обмеження у використанні земель розглянуто правові аспекти запропонованих Законом України «Про внесення змін до деяких законодавчих актів України щзодо планування використання земель» функиіональних зон території.

Досліджено зміни в земельному законодавстві щзодо повноважень розпоряджатися землями державної та комунальної власності, а також особливості використання земель приватної власності. Проаналізовано зміни до змісту изільового призначення як відомостей Державного земельного кадастру з у рахуванням змін до нормативного забезпечення поняття виду використання земельних ділянок.

Запропоновано ключові засади удосконалення та прийняття підзаконних актів з метою узгодження існуючого стану регулювання земельних відносин та майбутнього планування просторового розвитку територіальних громад.

Ключові слова: законодавче забезпечення, земельні відносини, нормативно-правові акти, просторове планування, територіальні громади.

Аврамчук Б.О., Кравченко А.Н., Застулка И.-О.Ю., Третяченко Д.В. ОСОБЕННОСТИ ЗАКОНОДАТЕЛЬНОГО ОБЕСПЕЧЕНИЯ ЗЕМЕЛЬНЫХ ОТНОШЕНИЙ ПРИ ПЛАНИРОВАНИИ ПРОСТРАНСТВЕННОГО РАЗВИТИЯ ТЕРРИТОРИАЛЬНЫХ ОБЩИН

Аннотация. Рассмотрень особенности нормативно-правового обеспечения регулирования земельных отночений в контексте изменений в отечественное законодательство. 
Освещуены основные угрозы, стоящче перед специиалистами землеустроительной сферы при планировании пространственного развития территориальных общин. Кроме того, проанализированьл особенности комплексного плана пространственного развития территории территориальной общзины как градостроительной документацуии на местном уровне и документациии по землеустройству одновременно, а также конщепцฺии интегрированного развития территории территориальной общины. Также, в контексте планирования пространственного развития территории и установления ограничения в использовании земель рассмотрено правовые аспекты предложенных Законом Украины «О внесении изменений в некоторые законодательные акты Украинь относительно планирования использования земель» функциональных зон территории.

Исследованы изменения в земельном законодательстве относительно полномочий распоряжаться землями государственной и коммунальной собственности, а также особенности использования земель частной собственности. Проанализировань изменения в содержаниии целевого назначения как сведений Государственного земельного кадастра с учета изменений в нормативного обеспечения понятия вида использования земельных участков.

Предложено ключевые основы совершенствования и принятия подзаконных актов с изелью согласования сущฺествующего состояния регулирования земельных отномений и будущеего планирования пространственного развития территориальных общзин.

Ключевые слова: законодательное обеспечение, земельные отночения, нормативно-правовые акты, пространственное планирование, территориальные общчины. 